\title{
Investigation of Airflow inside Floor Convector and Its Surrounding
}

\section{Josef Egert, Karel Frana}

Department of Power Engineering Equipment, Faculty of Mechanical Engineering, Technical University of Liberec. Studentská 1402/2, 46117 Liberec 1. Czech Republic.E-mail: j.egert@outlook.com, karel.frana@tul.cz

The article describes experimental and numerical investigation of airflow inside the floor convector. Analysis was divided to two parts. First part was airflow visualization. This part was realized in two areas. At first the visualization was realized in the area between a fan outlet and a heat exchanger inlet using a continual laser and a video camera. Then the visualization was realized in the region above the heat exchanger outlet with a Particle image velocimetry. At last the flow behavior in domain between the fan outlet and the floor convector outlet was analyzed with a numerical simulation. Commercial software ANSYS Fluent in version 15.0 was used. Results from the numerical simulation and the experiments were compared and the flow behavior was examined.

Keywords: floor convector, visualization, particle image velocimetry, numerical simulation

\section{Acknowledgement}

This work was financially supported by European Project no. CZ.1.07/2.3.00/20.0139 "Building of an excellent scientific team necessary for experimental and numerical modelling of fluid mechanics and thermodynamics".

\section{References}

[1] EGERT, J. (2015). Analýza proudění vzduchu uvnitř podlahového konvektoru a v jeho okolí. Liberec. Diploma thesis. Technical University of Liberec.

[2] FRANA, K., MULLER, M., LEMFELD, F. (2012). An Enhance of the Energy Effectiveness of the Convectors Used for Heating or Cooling. In: World Academy of Science, Engineering and Technology. International Science Index 67, s. 653 - 657.

[3] KUPPAN, T. (2013). Heat exchanger design handbook. [online]. 2nd ed. Boca Raton, Fla: CRC Press. ISBN 9781439842133.

[4] WEBB, R. L., KIM, Nae-Hyun. (2005). Principles of enhanced heat transfer. 2nd ed. Boca Raton: Taylor. ISBN 15-916-9014-5.

[5] KOPECKY, V. (2006). Laserova anemometrie. Liberec: Technical University of Liberec, ISBN 80-7083-945-7.

[6] Examining Spatial (Grid) Convergence. NPARC Alliance CFD Verification and Validation Web Site. [online]. Last edited 17. 07. 2008. [cit. 19. 5. 2015]. Available from: http://www.grc.nasa.gov/WWW/wind/valid/tutorial/ spatconv.html 